\title{
Allocative Efficiency of Resource use on Beekeeping in Chitwan District of Nepal
}

\section{Dhakal Shiva Chandra ${ }^{1}$, Regmi Punya Prasad ${ }^{2}$, Thapa Resham Bahadur ${ }^{2}$, Sha Shrawan Kumar $^{3}$ and Khatri-Chhetri Dilli Bahadur ${ }^{4}$}

\author{
${ }^{1}$ Assistant Professor, Agriculture and Forestry University, Rampur, Chitwan, Nepal \\ ${ }^{2}$ Professor, Institute of Agriculture and Animal Science, Rampur, Chitwan, Nepal \\ ${ }^{3}$ Professor, Agriculture and Forestry University, Rampur, Chitwan, Nepal \\ ${ }^{4}$ Seed Value Chain and Marketing Expert, CIMMYT, Kathmandu, Nepal
}

\begin{abstract}
Agriculture is facing with increasing pollinators decline all over the world affecting the functioning of regulatory and production service of pollination in adverse manner. Study on ways to conserve pollinating agents like bee is crucial in modern intensive agriculture. In this context a study was conducted to estimate the productivity and resource use efficiency of bee keeping in Chitwan district of Nepal. The study used data collected from randomly selected 48 bee keepers using face to face interview technique in the year 2014. Descriptive statistics, gross margin analysis, benefit cost analysis and multiple regression analysis using CobDouglas form were employed to achieve study objectives. It was found that farmers were rearing honey bee on an average of about 34 hives per farm with annual productivity of bee products equivalent to $36 \mathrm{Kg}$ honey per hive. Gross margin of beekeeping in the research area was found to be NRs. 3111.55 per hive with undiscounted benefit cost ratio of 1.71. Human labour use, expenditure on sugar, drugs and comb foundation and; migration cost were significantly contributing to the productivity of beekeeping and were required to increase their use by 39\%, 34\% and 74\%, respectively to achieve optimum profit. It was suggested to increase the level of all variable inputs through loan, subsidy and insurance to promote beekeeping enterprise in the study area for ensuring optimum profit to farmers and conservation of the most important agent of pollination.
\end{abstract}

Keywords-: Allocative efficiency, beekeeping, Chitwan, pollination, production function.

\section{INTRODUCTION}

Agriculture provides primary occupation to about $65.6 \%$ of total population in Nepal [1]. However, agriculture is only a means of subsistence for the majority and share only $31.4 \%$ of national Gross Domestic Product (GDP) to the economy [2]. Agricultural land is degrading by heavy use of chemical fertilizers, pesticides and other forms of pollutant technologies [3]. In addition such agrochemicals has led to decline of beneficial insects, such as crop pollinators and bioagents [4].

In the Hindu Kush Himalayan (HKH) region, evidence of the decline in pollinator numbers has been reported from apple farming in Jumla district of Nepal [5]. An increase in honey hunting and the ruthless hunting of the nests of wild honeybees is contributing to the decline in the population of indigenous honeybees [6]. Evidence of decline in population of Apis laboriosa in Kaski district of Nepal was reported in another similar study [7]. [8] reported pollination deficit on mustard in natural condition, and therefore, recommended management of honeybee for higher production and productivity of the crop. Pollinator loss in Chitwan has been attributed to habitat loss resulting from misuse of fertilizers and pesticides, reluctant in beekeeping, deforestation, loss of natural vegetation, increased commercial agriculture, use of high yielding varieties and; many other abiotic and biotic factors [9].

In the context of declining pollinators like honey bee, one of the key approaches available to promote the pollination management practice like beekeeping is the increase in their economic performance at farm level. This study aimed estimation of resource productivity and resource use efficiency of beekeeping in Chitwan district of Nepal. The findings of this research answers some resource use related issues on rearing of honey bee and alert the planners, policy makers and farmers to make necessary adjustments on inputs used in beekeeping for its commercialization which indirectly support to manage problems related with decline of natural pollinators.

\section{MATERIALS AND METHODS}

\subsection{Study site and sampling design}

The study was conducted in Chitwan district of Nepal. Six Village Development Committees (VDCs) namely Padampur and Jutpani from Eastern Chitwan; Phulbari and Mangalpur from Central Chitwan; and Meghauli and Sukranagar from Western Chitwan were selected randomly. Two farmers' group formed under Global 
Pollination Project (GPP) with size of twenty five group members in each were randomly selected from each VDC. Thus, a total of 50 farmers from each VDC and 300 farmers in total were the number of farmers selected for a study on different pollinator friendly agricultural practices adopting in the area. This study was part of those study on pollination management practices and beekeeping was found to be adopted by 45 farmers from among those 300 farmers under study. Primary data was collected with the use of semi-structured interview schedule using face to face interview technique in 2013-2014. Data collected from the face to face interview was cross checked with one group discussion in each VDC. Secondary data required for the study were collected from the publications of different governmental and nongovernmental organizations. Collected data were entered in SPSS and analyzed using STATA to have required inferential statistics. The details of different analytical techniques used are presented hereunder in different subsections.

\subsection{Cost of production}

All variable inputs like human labor, sugar, drugs, comb foundation and migration cost involved in beekeeping were considered and valued at current market prices to calculate cost of production. During cost estimation, both purchased and own farm produced inputs were accounted. Total variable cost $=\mathrm{C}_{\text {labor }}+\mathrm{C}_{\text {sugar }}+\mathrm{C}_{\text {drugs }}+\mathrm{C}_{\text {comb }}+\mathrm{C}_{\text {migration }}$ Where,

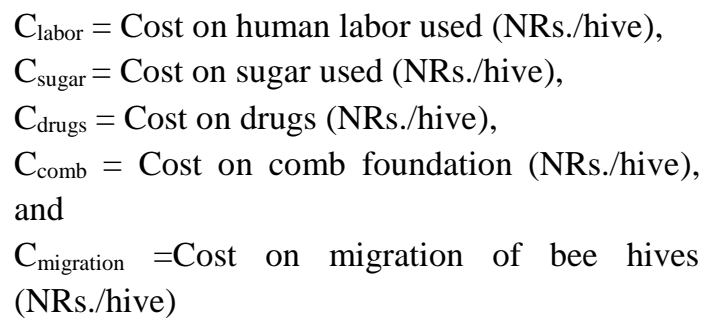

\subsection{Return and margin analysis}

Gross return was calculated by multiplying the total volume of product from beekeeping by the average price of the product at harvesting period [10]. Thus gross return was calculated by using following formula:

Gross return (NRs./hive) $=$ Total quantity produced of main and by products $(\mathrm{kg} / \mathrm{hive}) \times$ Price (NRs. $/ \mathrm{kg}$ )

Gross margin calculation was done to have an estimate of the difference between the gross return and variable costs. Gross margin was calculated by using the method as given by [11], using following formula;

Gross Margin (NRs./hive) = Gross return (NRs./hive) Total variable cost (NRs./hive)

\subsection{Benefit cost analysis}

Benefit cost ratio is the quick and easiest method to determine the economic performance of a business. It is a relative measure, which is used to compare benefit per unit of cost. Undiscounted benefit cost ratio was estimated as a ratio of gross return and total variable cost.
Thus, the benefit cost analysis was carried out by using formula:

$$
\mathrm{B} / \mathrm{C} \text { ratio }=\frac{\text { Gross return (NRs./hive) }}{\text { Total variable cost (NRs./hive) }}
$$

\subsection{Production function analysis}

Cobb-Douglas form of production function in the following form was fitted to examine the resource productivity, efficiency and return to scale.

$\mathrm{Y}=\mathrm{aX}_{1}{ }^{\mathrm{b} 1} \mathrm{X}_{2}{ }^{\mathrm{b} 2} \mathrm{X}_{3}{ }^{\mathrm{b} 3} \mathrm{e}^{\mathrm{u}}$

Where,

$$
\begin{aligned}
& \mathrm{Y}=\text { Gross return (NRs./hive), } \\
& \mathrm{X}_{1}=\text { Cost on human Labor (NRs./hive), } \\
& \mathrm{X}_{2}=\text { Cost on sugar, drugs and comb foundation } \\
& \text { (NRs./hive), } \\
& \mathrm{X}_{3}=\text { Cost of migration (NRs./hive), } \\
& \mathrm{e}=\text { Base of natural logarithm, } \\
& \mathrm{u}=\text { Random disturbance term, } \\
& \mathrm{a}=\text { Constant, and } \\
& \mathrm{b} 1, \mathrm{~b} 2 \text { and b3 represent Coefficients of } \\
& \text { respective variables. }
\end{aligned}
$$

The Cobb-Douglas production function in the form expressed above was linearised into a logarithmic function with a view of getting a form amenable to practical purposes using OLS technique as expressed below;

$\ln \mathrm{Y}=\ln \mathrm{a}+\mathrm{b}_{1} \ln \mathrm{X}_{1}+\mathrm{b}_{2} \ln \mathrm{X}_{2}+\mathrm{b}_{3} \ln \mathrm{X}_{3}$

Where,

$\ln =$ Natural logarithm, and rest of the other abbreviations are same as previous explanations.

Calculation of Return to Scale (RTS) in beekeeping was obtained by adding coefficients from log linearised CobbDouglas production function as follows;

$\mathrm{RTS}=\sum \mathrm{b}_{1}, \mathrm{~b}_{2}$ and $\mathrm{b}_{3}$

The sum of $b_{1}$ to $b_{3}$ from the Cobb-Douglas production function indicates the nature of return to scale.

Return to scale decision rule employed was;

RTS > 1: Increasing return to scale

RTS $=1$ : Constant return to scale

RTS $<1$ : Decreasing return to scale

\subsection{Resource use efficiency}

The allocative efficiency of a resource used was determined by the ratio of Marginal Value Product (MVP) of variable input to the Marginal Factor Cost (MFC) for the input and tested for its equality to one i.e. $(M V P / M F C)=1$. Following [12] the efficiency of resource use was calculated as;

$\mathrm{r}=\mathrm{MVP} / \mathrm{MFC}$

Where, $r=$ Efficiency ratio,

$\mathrm{MVP}=$ Marginal value product of a variable input, and $\mathrm{MFC}=$ Marginal factor cost

Decision rule for resource use efficiency is that a efficiency ratio (r) equal to unity indicates the optimum use of that factor, the ratio more than unity indicates that

Page | 1448 
gross return could be increased by using more of the resource and the ratio of less than unity indicates the excess use of resource which should be decreased to minimize the loss [13]. Again, the relative percentage change in MVP of each resource required to obtain optimal resource allocation, i.e. $\mathrm{r}=1$ or $\mathrm{MVP}=\mathrm{MFC}$ was estimated using the following equation below [14];

$\mathrm{D}=(1-\mathrm{MFC} / \mathrm{MVP}) \times 100$

Or, $\mathrm{D}=(1-1 / \mathrm{r}) \times 100$

Where, D represents absolute value of percentage change in MVP of each resource, and $r$ for efficiency.

\section{RESULTS AND DISCUSSION}

\subsection{Cost, returns and profit from honey beekeeping}

Farmers were rearing honey bee on an average of 33.73 hives per farm with productivity of $36 \mathrm{~kg} / \mathrm{hive}$ honey equivalent (Table 1). It was slightly less compared to $40.71 \mathrm{Kg} / \mathrm{hive}$ as found by [15] . In the research area, gross return of beekeeping was estimated to be about NRs. 7,482.2, while total cost of beekeeping per hive was estimated to be about NRs. 4,370.57. Gross margin from beekeeping in the research area found to be NRs. $3,111.55$ per hive. It was observed that the overall undiscounted benefit cost ratio of beekeeping in the research area was 1.71 which were slightly varied with some previous findings. [16] reported it to be 2.41 and [9] reported it to be 1.81 . Such better benefit cost ratio advocates very strongly on the profitable potential of beekeeping in the study area.

\subsection{Resource productivity on beekeeping}

Estimated values of regression coefficients and related statistics of Cobb-Douglas production function of beekeeping are shown in Table 2. Three explanatory variables namely human labor cost, expenditure on sugar, drug and comb foundation and; migration cost were considered to show their effects on production of honeybee. All of those three variables were significantly contributing to the productivity of beekeeping at $1 \%$ level of significance. The regression coefficient for human labor cost was 0.361 , which had depicted that with $100 \%$ increase in cost on human labor, gross return from beekeeping could be increased by about $36 \%$. Similarly, with the increase in expenditure on sugar, drug and comb foundation by $100 \%$, gross return could be increased by about $31 \%$ as its coefficient is 0.306 . Likewise, with $100 \%$ increase in migration cost, gross return could be increased by about $17 \%$ as its coefficient is 0.169 .

The coefficient of multiple determination $\left(\mathrm{R}^{2}\right)$ of the production function was 0.77 for beekeeping which indicated that about $77 \%$ of variations in gross return have been occurred due the explanatory variables, which were included in the model (Table 2). The value of adjusted $\mathrm{R}$ square was 0.75 indicating that after taking into account the degree of freedom (df), $75 \%$ of the variation in the dependent variable explained by three explanatory variables included in the model.

The measures of the overall significance of the estimated regression was shown through $\mathrm{F}$ value. $\mathrm{F}$ value was 46.44 and it was significant at $1 \%$ level implying that all the explanatory variables included in the model are important for explaining the variation of the productivity of beekeeping. Returns to scale reflect the degree to which a proportional change in the output due to proportionate change in input. The sum of the coefficients of different inputs stood at 0.836 for honey production (Table 2). This indicates that the production function exhibited a decreasing return to scale and implied that if all the inputs specified in the function are increased by $100 \%$ income will increase by about $83.6 \%$.

\subsection{Resource use efficiency on beekeeping}

The estimated MVP and MFC of different inputs used in beekeeping production are presented in Table 3 . After the analysis of prices of both inputs and output, it was evident that ratio of MVP to MFC of all the factors of production were positive and greater than one. This revealed that they were being under-utilized and profit could be increased by increasing their level of use. All the inputs human labor, expenditure on sugar, drug and comb foundation and especially, migration cost were underutilized on beekeeping in study area. The adjustment in the MVPs for optimal resource use indicated that for optimal allocation of inputs their level of use should be increased. Human labor was needed to increase by $39 \%$ to obtain the optimum profit from beekeeping enterprises. Similarly, expenditure on sugar, drug and comb foundation and; migration cost were required to be increased by $34 \%$ and $74 \%$, respectively (Table 3).

\section{CONCLUSIONS}

The research conducted to assess the productivity and resource use efficiency of beekeeping revealed that farmers were rearing honey bee on an average of 33.73 hives per farm with productivity of honey equivalent to $36 \mathrm{Kg}$ per hive. Gross margin of beekeeping in the research area found to be NRs. 3111.55 per hive with observed value of undiscounted benefit cost ratio of 1.71 . Three explanatory variables namely human labor cost, expenditure on sugar, drug and comb foundation and; migration cost significantly contributed to productivity of honey be at $1 \%$ level of significance. Return to scale value of honey beekeeping was 0.836 and reflected the decreasing return to scale. Human labor, expenditure on sugar, drug and comb foundation and especially, migration cost were underutilized on beekeeping in study area. It was suggested to increase the labour use, materials use like sugar, drug and comb foundation and, migration cost by $39 \%, 34 \%$ and $74 \%$, respectively to harvest

Page | 1449 
optimum profit by farmers. The research findings suggest that there is ample opportunity of promoting beekeeping in study area with the recommended adjustment in resource use to harvest optimum profit. The level of underutilized resources in beekeeping can be promoted through extension, subsidy, insurance and loan facility to the beekeeping enterprises.

\section{ACKNOWLEDGEMENTS}

The authors express their gratitude to the Global Pollination Project (GPP) for providing partial financial support to conduct this study. We would also like to express our deepest gratitude to our colleagues for their direct and indirect help for the completion of research and heartwarming appreciation goes to respondents of the study site for their cooperation, time and valuable information.

\section{REFERENCES}

[1] MOAD. (2015): Statistical information on Nepalese agriculture. Government of Nepal, Agribusiness promotion and statistics division, statistics section, Singh Durbar, Kathmandu, Nepal.

[2] MOF. (2016): Economic survey. Government of Nepal, Singh Durbar, Kathmandu, Nepal.

[3] Deshar, B. D. (2013): An Overview of Agricultural Degradation in Nepal and its Impact on Economy and Environment. Global Journal of economic and social development. 3:1. pp1-20. Research India publications.

[4] Thapa, R.B. (2006): Honeybee and other insect pollinators of cultivated plants: A review. Journal of Institute of Agriculture and Animal Sciences. 27: 123.

[5] Partap, T. (2001) Mountain agriculture, marginal land and sustainable livelihoods: Challenges and opportunities. International Symposium on Mountain Agriculture in HKH Region (May 21-24, 2001). International Centre for Integrated Mountain Development (ICIMOD), Kathmandu, Nepal.

[6] Partap, U. (2010) : Innovations in revival strategies for declining pollinators with particular reference to the indigenous honeybees: Experiences of
ICIMOD's initiatives in the Hindu Kush-Himalayan region. Pest Management and Economic Zoology 18: 85-95.

[7] Ahmad, F., Joshi S. R., Gurung M. B. (2003): The himalayan cliff bee Apis laboriosa and the honey hunters of the Himalayas, Volume 1. ICIMOD. Kathmandu.

[8] Pudasaini, R., Thapa, R.B. (2014): Effect of pollination on rapeseed (Brassica Campestris L. Var. toria) production in Chitwan, Nepal. The Journal of Agriculture and Environment 15: 41-45.

[9] Devkota, K. (2012): Economics of pollination and pollination management practices in Chitwan district, Nepal. M.Sc. thesis. Tribhuvan University, IAAS, Chitwan, Nepal.

[10]Dillon, J. L., Hardaker, J.B. (1993): Farm management research for small farm development. Food and Agriculture Organization of the United Nations, Rome.

[11] Olukosi, J.O., Isitor, S. U., Ode, M.O. (2006): Introduction to agricultural marketing and prices: principle and application. American Journal of Agriculture and Forestry 2(4): 199-205.

[12] Goni, M., Umar, M., Sman, U. (2013): Analysis of resource-use efficiency in dry season vegetable production in Jere Borno State, Nigeria. Journal of Biology and Agriculture Health 3(19): 18-23.

[13] Okon, E.T. (2005): Comparative analysis of large and small scale farmers resource use efficiency in food crop production in Akwa-Ibom state, Nigeria. Journal of Agriculture and Food science 3(1): 75-84.

[14] Mijindadi, N.B. (1980): Production efficiency on farms in northern Nigeria. PhD dissertation. Cornell University, USA.

[15] Vaziritabar, S., Esmaeilzade, S. M. (2016): Profitability and socio-economic analysis of beekeeping and honey production in Karaj state, Iran. Journal of Entomology and Zoology Studies 2016; 4(4): 1341-1350

[16] Devkota, K. H. (2006): Benefit-Cost Analysis of Apiculture Enterprise: A Case Study of Jutpani VDC, Chitwan, Nepal. Journal of Institute of Agriculture and Animal Science 27:119-125

Table.1: Economic statement of beekeeping in Chitwan during 2013-2014

\begin{tabular}{lc}
\hline Measuring criteria & Average value \\
\hline Average number of hives per farm & 33.73 \\
Productivity-main product equivalent (Kg/hive) & 36 \\
Gross return (Rs./hive) & $7,482.12$ \\
Total cost (Rs./hive) & $4,370.57$ \\
Gross margin (Rs./hive) & $3,111.55$ \\
Benefit cost ratio & 1.71 \\
\hline
\end{tabular}

Source: Field survey, 2014 
Table.2: Estimated values of coefficients and related statistics of Cobb-Douglas production function of beekeeping

\begin{tabular}{lllll}
\hline Factors & Coefficient & Std. Error & t-value & Sig. level \\
\hline Constant & $3.009^{* *}$ & 0.777 & 3.87 & 0.000 \\
Human labor cost (Rs./hive) & $0.361^{* *}$ & 0.114 & 3.17 & 0.003 \\
Expenditure on sugar drug and comb & $0.306^{* *}$ & 0.306 & 3.09 & 0.004 \\
foundation (Rs./hive) & & & 3.72 & 0.001 \\
Migration cost (Rs./hive) & $0.169^{* *}$ & 0.045 & & 0.001 \\
F-value & $46.44^{* *}$ & & \\
R square & 0.77 & & \\
Adjusted R-square & 0.75 & & \\
Return to scale & 0.836 & & \\
\hline
\end{tabular}

Note: **Significant at $1 \%$ level of confidence

Source: Field survey, 2014

Table.3: Allocative efficiency of inputs used in beekeeping in Chitwan during 2013-2014

\begin{tabular}{|c|c|c|c|c|c|c|}
\hline $\begin{array}{l}\text { Inputs } \\
\text { (Rs./hive) }\end{array}$ & $\begin{array}{c}\text { Geometric } \\
\text { mean }\end{array}$ & MVP & MFC & $\begin{array}{l}\text { MVP/ } \\
\text { MFC }\end{array}$ & Efficiency & $\begin{array}{c}\text { Adjustment required } \\
\qquad(\%)\end{array}$ \\
\hline Human labor & $1,618.86$ & 1.63 & 1.00 & 1.637 & Under utilized & 38.897 \\
\hline $\begin{array}{l}\text { Sugar, drugs and comb } \\
\text { foundation }\end{array}$ & $1,474.25$ & 1.52 & 1.00 & 1.523 & Under utilized & 34.353 \\
\hline Migration cost & 329.71 & 3.76 & 1.00 & 3.762 & Under utilized & 73.417 \\
\hline
\end{tabular}

Source: Field survey, 2014 